\title{
Correct your own exam. Exercises for university students to develop writing skills in biology
}

\author{
José A. Hódar ${ }^{1 a}$, Carmen Pérez-Martínez ${ }^{1}$, Amalia E. Morales ${ }^{2}$, Eugenio Martín-Cuenca ${ }^{2}$ \\ and Enrique Iáñez-Pareja ${ }^{3}$ \\ ${ }^{1}$ Departamento de Ecología, Universidad de Granada, Facultad de Ciencias, Avda. Fuentenueva s.n. \\ E-18002 Granada, Spain \\ ${ }^{2}$ Departamento de Zoología, Universidad de Granada, Facultad de Ciencias, Avda. Fuentenueva s.n. \\ E-18002 Granada, Spain \\ ${ }^{3}$ Departamento de Microbiología, Universidad de Granada, Facultad de Ciencias, Avda. Fuentenueva \\ s.n. E-18002 Granada, Spain
}

\begin{abstract}
This work describes a project intended to improve an essential aspect of student learning, i.e. writing essay tests, directed to students of the Undergraduate Degree in Biology at the University of Granada (Spain). Previous results indicate that most students are well prepared and understand most of the concepts basic to Biology, as reflected in the multiple-choice questions, but perform poorly when answering the essay questions. This work seeks to improve speech, writing, and conceptual organization of student responses in the essay questions, and to maintain skills developed during this project. The core of the project was a session of correcting written exercises, conducted in groups during class time and led by the teacher. The analysis of the scores reveals better student performance, reflecting the usefulness of these exercises for improving the students' skills in written expression.
\end{abstract}

Keywords: multiple-choice tests vs. essay questions; Biology students; self-correction; writing skills; written expression.

\section{Introduction}

The first year at the university represents a challenge to students coming from high school, and many studies analyze the way in which students face this transition to higher education [7]. Kift [5] listed six principles as being basic to first year curriculum and that support student initiative, success, and retention in this learning process. These principles can be enumerated as: 1) student transition to university and 2) engagement with learning; 3) the design of learning tasks and 4) the nature and timing of their assessment; 5) the

\footnotetext{
${ }^{\text {a }}$ Corresponding author: jhodar@ugr.es
} 
diversity of the student body; and 6) evaluation and monitoring of both student progress and the learning programs.

Evaluation, the last point mentioned by Kift [5], is frequently overlooked as a learning tool. However, it is an inseparable part of any education process, since it plays a crucial role in any student's learning [2]. The course evaluation is a valuable tool of teaching and learning because it can provide useful feedback both for teachers and their institution concerning the educational quality [1]. In this sense, some instructors use exams expressly as learning tools [6]. After the exam, students are asked to analyze why they answered questions incorrectly and then research the correct answer. It has been suggested that this process clears up misconceptions and enhances learning.

Exams are used as an assessment tool, but are also a valuable teaching tool if students revisit the material and review flaws to clarify misunderstandings [3]. Instructors often encourage students to review their exam answers in order to understand why they answered questions incorrectly. The identification and correction of misconceptions is a metacognitive process that helps students improve their studying for the next exam [6].

This work describes a project aimed at improving an essential aspect of student learning-writing answers in the written tests. The project is directed at students of the mandatory subject entitled "Ecological Concepts", given during the first semester of the Undergraduate Degree in Biology at the University of Granada (Spain). The results of the written tests from previous years indicate that most students are well prepared and understand most of the concepts basic to Biology, as reflected by the right answers in the multiple-choice questions. Conversely, the performance of these students is rather poor when they answer essay questions. During the 2011-2012 academic year the average grade on multiple-choice questions was $7.41 \pm 0,11$ (mean $\pm \mathrm{SE}, \mathrm{n}=191$, score 0 -10), while for essay questions it was $4.79 \pm 0.15$. Thus, the goal of this study was twofold: 1 ) to improve speech, writing, and conceptual organization of student responses in the essay questions, over the short-term, in order to foster better results on the written tests and thereby enhance overall student performance in the subject; and 2) to encourage students to maintain the skills gained during this project over the long-term, as an ongoing aspect of their development over their academic career. These skills are an essential part of preparation for professional life at any university [4].

\section{Material and Methods}

The project was implemented during the 2012-2013 academic year. The core of the project was a session of correcting written exercises, conducted during class time. The teacher selected from previous courses essay questions on the key concepts of the subject matter. Students wrote the answer to a question within a given time limit and then analyzed the strengths and weaknesses of their answers with the help of the teacher and an ad hoc template. Also, for analysis, the teacher displayed student responses from previous courses as examples of different scores (e.g. 2-5-9, on a 0-10 scale). Later, the teacher provided a template list (Table 1) for the students to analyze their responses. Each student scored from 1 to 5 (1-very low to 5-very high) both his or her own answer as well as the answers from previous years in the exams provided by the teacher. Then, the teacher explained and commented on these responses, emphasizing positive and negative points. Afterwards, students repeated the scoring of their own answers, as well as the answers from previous years. In this way, students became aware of the most common mistakes of expression when writing their answers, thereby improving their written expression. 


\section{Results and Discussion}

Here we illustrate the procedure with a working example of one of the main concepts in Biology: cell theory.

Q: Schleiden and Schwann made a breakthrough in the cell theory. Discuss.

Students were asked to write a short essay answer. Then, the teacher provided the following three responses from previous years:

Table 1. The template list for the analysis of responses to the question posed. Columns indicate the scores given by the student to his or her own answer to the question, as well as to the answers of different scores given by pupils of past years and selected by the teacher

\begin{tabular}{|c|c|c|c|c|}
\hline Positive aspects & $\begin{array}{l}\text { Own } \\
\text { answer }\end{array}$ & $\begin{array}{l}\text { Low } \\
\text { score }\end{array}$ & Average & $\begin{array}{l}\text { High } \\
\text { score }\end{array}$ \\
\hline Main concept well expressed & $\ldots$ & $\ldots$ & $\ldots$ & $\ldots$ \\
\hline Answer well explained & $\ldots$ & $\ldots$ & $\ldots$ & ... \\
\hline $\begin{array}{l}\text { Arguments clearly presented with orderly } \\
\text { reasoning }\end{array}$ & $\cdots$ & $\cdots$ & $\cdots$ & $\cdots$ \\
\hline Scientific terms properly used & $\ldots$ & $\ldots$ & $\ldots$ & $\ldots$ \\
\hline The answer clearly written in rational order & $\cdots$ & $\ldots$ & $\cdots$ & $\cdots$ \\
\hline Negative aspects & $\cdots$ & $\ldots$ & $\cdots$ & $\cdots$ \\
\hline Misconceptions & $\ldots$ & $\ldots$ & $\ldots$ & $\cdots$ \\
\hline Contradictions & $\ldots$ & $\ldots$ & $\ldots$ & $\cdots$ \\
\hline Ideas related to the topic but incoherent & $\cdots$ & $\cdots$ & $\cdots$ & $\cdots$ \\
\hline $\begin{array}{l}\text { Circular reasoning, padding, redundancies, truisms, } \\
\text { ambiguities }\end{array}$ & $\cdots$ & $\cdots$ & $\cdots$ & $\cdots$ \\
\hline Unintelligible sentences, faulty reasoning & $\cdots$ & $\ldots$ & $\ldots$ & $\cdots$ \\
\hline Scientific terms absent or misused & $\ldots$ & $\ldots$ & $\ldots$ & $\cdots$ \\
\hline Common terms misused & $\cdots$ & $\cdots$ & $\cdots$ & $\cdots$ \\
\hline $\begin{array}{l}\text { Disorderly response, illegible handwriting, bad } \\
\text { spelling }\end{array}$ & $\cdots$ & $\cdots$ & $\cdots$ & $\cdots$ \\
\hline Careless response (lines struck out) & $\ldots$ & $\ldots$ & $\ldots$ & $\ldots$ \\
\hline Overall score before/after & $\ldots$ & $\ldots$ & $\cdots$ & $\ldots$ \\
\hline
\end{tabular}

Answer \#1 (average score, 4-6)

Scheleiden and Schwann were a botanist and zoologist, respectively, led to a breakthrough in cell theory because, in the middle of discussions on the origin and correct definition of the cell, they established a series of developments regarding cell theory. Schleiden studied plants and concluded that plants were composed of cells (the first study of the cell theory including animals), and these grew by increasing the amount of cells and the cell was formed from the nucleus. Schwann noted that the same cells with certain characteristics, which his botanical friend observed, were seen by him while studying a living being. They established the 2nd principle of cell theory: "the cell is the fundamental and structural unit of all living things", later the following principle arose "the cell is the functional unit of all living things." 
Comments by the teacher:

Although wordy and rambling, this is still an incomplete answer, with serious deficiencies in expression. Plus, there are erroneous and unintelligible details. "Schwann noted that the same cells with certain characteristics, which his botanical friend observed, were seen by him the while studying a living being [refers to an animal? Plants are not?] ... They established the $2^{\text {nd }}$ principle of the cell theory: 'the cell is the fundamental and structural unit of all living things' later the following principle emerged 'the cell is the functional unit of all living things"',. Words seem to be missing in this sentence. At this point it is hard to say how many principles the cell theory has.

Difficult to read, incomprehensible writing, parts struck out. The first sentence repeats what is asked, but offers no new information, and has circular reasoning. It would be advisable for students to structure their response before starting to write and reread it after finishing.

Answer \#2 (high score, 8-10)

Schleiden and Schwann independently concluded that all living things were made up by cells, from their research on plants and animals, respectively. This statement today is the first principle of the cell theory and led other scientists such as Virchow to the discovery of other principles.

Comments by the teacher:

Write clearly and concisely about the main contribution of the authors to cell theory.

Precision and synthesis are assets.

Answer 3 (low score, 1-3)

Planted the foundations of cell theory, establishing the cell as an organism by which all living organisms are formed. Before them a solid cell theory was not established, thus opening the field to research on their functions and types.

Comments by the teacher:

Answer unclear, writing "establishing the cell as an organism by which all living organisms are formed...". This is a basic error and lowers the score. The writing is badly deficient.

Expected answer:

Schleiden, studying plants, made a breakthrough by discovering that plants are composed of cells, theorizing that the cell is the basic unit of plant structure. The zoologist Schwann extended Schleiden's cell theory to animals, leading to the first principle of the cell theory: all living things are made up of cells. Both scientists rejected vitalism and proposed a mechanistic explanation.

These classroom exercises (questions and answers from students with different scores, along with comments on student responses made by the teacher) were made available to the students in PowerPoint format. In these examples the correct and incorrect aspects of each response are indicated. This information guided the students when preparing the subject matter to study, and in fact was used when preparing the written examinations.

The analysis of the scores earned by students in the 2011-2012 and 2012-2013 academic years reveals significant differences with respect to the results on the essay questions, scores being higher in the 2012-2013 academic year ( $4.79 \pm 0.15$ vs. $5.53 \pm 0.14$, Student's $T$ test $\mathrm{t}=3.5445, \mathrm{p}=0.0004, \mathrm{n}=191$ and 202 respectively), whereas scores on the multiplechoice questions did not significantly differ between years (7.41 \pm 0.11 vs. $7.63 \pm 0.11$, $\mathrm{t}=1.3968, \mathrm{p}=0.1633$ ).

These results highlight the usefulness of these exercises for improving the students' writing. Offering exam corrections encouraged the students to look over their own tests. On being confronted with answers by students from previous years, as well as to their own 
answers, and having access to the criteria and examples provided by the teacher, students understood in what way each wrong answer they gave was incorrect and what constituted a correct answer. This exercise required students to analyze where their thinking was flawed [6], thus enabling students to go through this metacognitive process.

\section{Acknowledgments}

This study was supported by the project Ejercicios para el desarrollo de habilidades en la expresión escrita de los estudiantes de $1^{\circ}$ de Biología (12-185), funded by the Universidad de Granada.

\section{References}

1. Frydrychova Klimova, B., Self-reflection in the course evaluation. Procedia - Social and Behavioral Sciences, 141, 119-123, (2014a).

2. Frydrychova Klimova, B., Evaluation methods as an effective tool for the development of students' learning. Procedia - Social and Behavioral Sciences, 152, 112-115, (2014b).

3. Henderson, C., \& Harper, K. A., Quiz corrections: improving learning by encouraging students to reflect on their mistakes. The Physics Teacher, 47, 581-586, (2009).

4. Jerde, C.L., \& Taper, M. L., Preparing undergraduates for professional writing. Journal of College Science Teaching, 33(7), 34-37, (2004).

5. Kift, S., A transition pedagogy for first year curriculum design and renewal. FYE Curriculum Design Symposium. Queensland University of Technology, Brisbane, 5-6 February, (2009).

6. Mynlieff, M., Manogaran, A., St. Maurice, M., \& Eddinger, T., Writing assignments with a metacognitive component enhance learning in a large introductory Biology course. CBE - Life Sciences Education, 13(2), 311-321, (2013).

7. Rayner, G., \& Cridland, C., Preparing for tomorrow today: the first year experience as foundation. First Year in Higher Education Conference 2009. Townsville, Queensland, Australia, (2009). 